\title{
Multi-Partyism versus Democracy in Southern Africa: "Whither Lesotho"
}

\author{
By Khabele Matlosa
}

\section{Introduction}

Multi-Partyism as a specific phenomenon in political systems and processes refers to a political environment that gives room to an emergence and operation of a multiplicity of political parties in a particular political setting. This is multi-partyism as a condition. Multipartyism, however, may also be conceptualized as a political process characterised by legally registered political parties contesting for state power in a given political setting.

Multi-Partyism, both as a condition and process, may obtain either in a hegemonic political set-up or a free and fair political competition of existing political parties. Put differently, multi-partyism may prevail in a situation of political monopoly of the ruling party or in a free and fair political competition that ensures smooth change of government overtime depending on various parties political strength in respect of resources and strategies. We will come back to the hegemonic political set-up and free and fair competition later. In a rather scathing observation Molomol argues that

"Multi-partyism is a Western political idea which through its articulation of basic political freedoms mystifies class rule, in the case of Botswana rule by the petty bourgeoisie. The two-party systems which exist in the advanced democracies of Britain and United States do not reflect real opposition per se, but the institutionalisation of hegemony. In another formulation, they represent the hegemonic influence of the hegemonic class, the bourgeoisie."

This is an apt observation which does not only alert us to the class character of political processes, but much more importantly brings into sharp relief the contradictions of multipartyism. Mandaza and Sachikonye 2 corroborate Molomo's observation as follows:

"Much of the conceptualisation of democracy today, therefore, borrows extensively from the discourse of the bourgeois revolutions which ushered in the main features of

1 M.Molomo / B. Mokopakgosi (eds.), Multi-Party Democracy in Botswana, Sapes books, 1991.

2 I. Mandaza / L. Sachikonye (eds.), The One-Party-State and Democracy: The Zimbabwe Debate, Sapes books, 1991. 
Westem democracy with its stress on property rights, individual rights and such rights as those relating to voting, freedom of association, and speech among others. This discourse has tended to equate the democratic model with a 'free market economy' a capitalist economic system. Although capitalist development in the West was inextricably linked with the bourgeois revolutions, this did not ensure that the new social and political systems put into place were necessarily 'democratic'."

On the contrary to Molomo 3 and Mandaza and Sachikonye4 above, the US Secretary of State Herman Cohen (Voice of America, October 2, 1991) provides a conventional wisdom of Westem conceptualisation of democracy:

"Pluralistic democracy is the friend of economic growth. This single-party system is inheritently unfair and inimical to economic growth. Pluralistic democracy channels resources to the most productive populations and gives maximum scope to the private sector. African states need to adopt a free market and the democratic system of govemment. Africa cannot have one without the other."

In the very same vein the British Minister for Overseas Development, Lynda Chalker, argues that one of the guiding principles of "good government" is "Sound economic and social policies which allow free reign to Market Forces"5.

Following closely on the footsteps of Cohen and Chalker above, De Klerk, the President of South Africa, has this to say:

"If we prevent the free-market system from developing, we won't have economic growth, and no govemment - not even an ANC-dominated one - will be able to manage the problem." 6

The central questions (which are of academic and policy importance) that confront us in this debate are

(a) whether multi-partyism, in and of itself engenders democracy or vice versa,

(b) whether both multi-partyism and democracy (whatever meaning may be attached to them) are political projects of the ruling classes together with their national and international allies and

(c) whether or not some African Countries (e.g. Botswana) have thus far experienced mere multi-partyism rather that democracy as it were.

5 Sapem, Vol. 4, No. 11, 1991; Sapem, Vol. 5, No. 1, 1991.

6 The Star, November 19, 1991. 
(d) Does democracy merely denote holding general elections per se or does it involve a sustainable social transformation that will lead to improvement of the economy particularly in favour of the disadvantaged.

Democracy, as both a condition and process, is much more complex and intriguing to conceptualise that multi-partyism. Democracy is not only beset with teething definitional problems but it also has grave operational problems for African governments.

In another formulation, democracy is the most nebulous concept to grasp easily through conventional definitions. The complexity of democracy, as both a concept and a political process, is further compounded by the fact that it is often overwhelmingly loaded with ideological predilections and ideosyncracies of a particular class or coalition of classes. To be more precise, therefore, a definition of democracy by one class in society may as well mean autocracy for another. It is largely on the basis of this irony that Shivji7 observes in a rather poignant fashion:

"The debate on democracy among African Scholars is threatening to become an unabashaed celebration of liberalism ... So long as the so-called debate on democracy remains imprisoned within the four walls of liberalism, I dare say the debate has not begun - it may be a diversion but not a debate."

From this premise Shivji8 then characterises democracy as constituting "an ideology of resistance and struggle of the larger masses and popular classes of the people". With a somewhat subtle sophistication of argument Shivji then concludes that as an ideology of resistance or struggle, democracy can only be cast in terms of popular democracy whose actual parameters can only be determined in real class struggles in given socio-political contexts and concrete historical epochs.

Given the complexity of democracy as a concept and political process and the noncommittal nature of African govemments towards democratisation, it is thus less of a consternation that there was no thorough debate on democratisation in the recent Leadership Forum of the 19 - 23 May, 1991 held in Kampala, Uganda. In this respect the Kampala Document - a declaration of the Leadership Forum - only made a minimalist, and indeed ambiguous resolution that:

"Every country would ensure that there is no hindrance to alternative ideas, institutions and leaders competing for public support. In the case of multi-party pluralism, this prin-

7 I. Shivji, Pitfalls on the Debate on Democracy, Sapem, Vol. 3, No. 5, 1990.

8 Ibid. 
ciple requires every participating members to ensure the separation of party from the state."9

Our reading of the above quote reveals the extent to which the participating leaders were oblivious of the core of democratic transformation in African societies. Be that as it may, even the above quote is easier said than done given the track-record of those honourable African leaders who congregated in Kampala.

The remaining section of this paper will assume the following format. Section one attempts to synthesise in a synoptic fashion the state of the art and thrust of the current democracy debate in Africa which Shivji refers to above. Section two provides a detailed account and analysis of democracy, or lack thereof, in Lesotho. The conclusion revisits our major observations and provides scenarios for democratic transformation in Lesotho given the kaleidoscopic developments taking shape whithin the world politics.

\section{African Democracy Debate Revisited}

Recently there has emerged a rich academic discourse on democracy in Africa which to my mind seems to transcend the Lincolnian "Govemment of the people, by the people, for the people" thesis, as in the case of Molomo and Shivji referred to above. This widely known Lincolnian thesis is too abstract to apply to real political situations in Africa. In the first instance, the question arises as to what type of "government" Lincoln is referring to. In a word, what is the class configuration within that particular government? Secondly, which "people" is Lincoln referring to? Civil society is not a homogenous political or economic entity.

Instead of being abstract and highly philosophical, the emerging debate on democracy in Africa is couched in such a way that it interrogates the obtaining socio-economic and political realities of the continent. 10 Whether or not this discourse does its task sufficiently and whatever ideological-cum-theoretical instruments are put to use to conceptualise Africa's political process is not our concern here.

It is worth noting, though, that the central thrust of this discourse revolves around the following pillars: Firstly, it addresses the problematique of the "developmental" state in

9 The Kampala Document, African Forum, Vol. 1, No. 3, 1991.

10 P. Anyang Nyongo (ed.), Popular Struggles for Democracy in Africa, zed/unu, London 1987; Democracy and the Economy, Sapem, Vol. 3, No. 5, 1990; J. Holm/ P. Molutsi (eds.), Democracy in Botswana, Macmillan, London 1989; I. Mandaza / L. Sachikonye (eds.), cf. fn. 2; M. Molomo I B. Mokopakgosi (eds.), cf. fn. 1; Sapem, Vol. 3, No. 5, 1990. 
Africa. In other words the extent to which democracy in Africa has been underminded by state's emphasis on economic growth, law and order and national unity. Anyang Nyongo 11 posits that "there is a definite correlation between the lack of democratic practices in African politics and the deteriorating socio-economic conditions". Mandaza and Sachikonye12 reinforce this argument by observing that the African democracy debate has centred on the interface between democratic process on the one hand and development and national unity on the other. They conclude:

"African states have neglected the linkage between politics and economic development by asserting that political order and stability, but not democracy, were the pre-conditions for economic growth and prosperite ... Generally the argument by most African leaders that development and national unity should come first before democracy has been subjected to a penetrating critique."13

It is this very "ideology of developmentalism" which is in fact responsible for the fiasco of African experiments of political stability and economic development. As it were, political processes in Africa remain a far away cry from democracy, the multi-party systems notwithstanding.

The second important aspect of the democracy debate in Africa is accountability. Anyang Nyongo 14 further contends, development issues and socio-economic crisis cannot be meaningfully discussed without discussing problems relating to the nature of state power. A democratic state, therefore, must be:

"a state responsive to demands of the social forces that provide it with its power base, its legitimacy, its ability to hold social conflicts in check and its capacity to ensure the reproduction of society as a whole." 15

Concomitant to the above observation is Mkandawire's 16 contention that lack of accountability leads to gross abuse of public resources and the public Kitty and, thus, low levels of accumulation. African political systems are replete with a high rate of corruption, maladministration and inefficiency which phenomena have characterised the post-independence euphoria of nationalisation and indigenisation.

11 Ibid.

12 Cf. fn. 2.

13 Cf. fn. 2.

14 P. Anyang Nyongo (ed.), cf. fn. 10.

15 Ibid.

16 T. Mkandawire, Democracy in Africa, Sapem, Vol. 3, No. 5, 1990. 
The third aspect of the African democracy debate has to do with the role of non-governmental organisations (NGO's) in civil society. In this particular regard, a variety of NGO's have been discussed including the Social Movements 17 and the church18. In a general sense NGO's are beginning to assert themselves in African civil society with a view of having an imprint on the socio-economic destiny of the continent. This is more glaring now in the context of the domestic and international clamour for democratisation of society.

Whether the present pervasiveness of NGO's is a natural evolutionary metamorphosis or a reflection of the declining role and legitimacy of the state is not a subject of discussion here. Suffice it to note that NGO's are presently a critical force to reckon with in African politics. In the case of Lesotho, in particular, it is important to note the changing role of the church in political processes (in particular Lesotho Evangelical Church - LEC and the Roman Catholic Church). Since independence the above churches experienced a clear-cut political rift thrusting the former into the ranks of the BCP-major opposition and the the latter into the into the BNP - then the ruling party. But it is interesting to note that dramatic turns and twists of Lesotho's political landscape since the early 1970s have somewhat changed this pattem. At the present moment the major religious denominations in the country are striving towards unity. This unity is, in the main, aimed at facilitating the church to break away from rigid political stereotypes in order for this institution to participate meaningfully in the "democratisation" process. This is lucidly reflected in the current attempts by the church to organise a National Conference on the 29 - 31 October 1991 to discuss

(a) current political situation and obstacles to democratisation by 1992 ,

(b) current economic situation,

(c) the role of the church.

The government has in principle agreed to partake in this conference. Paradoxically, the BCP has withdrawn from this conference at the eleventh hour for some obscure reasons. 19

The fourth aspect of the African democracy debate revolves around human rights and a democratic constitutional order.20 A careful reading of Shivji clearly reveals that human rights under whatever form of political regime and in any type of political system are not a mere legal desiderata but rather an inalienable political entitlement of the governed. Even on this score, African political systems have a tremendously unimpressive record as clearly reflected even in Amnesty Intemational Reports. According to Shivji academic discourse

17 Mandani, Social Movements and Constitutionalism in the African Context, in: I. Shivji (ed.), State and Constitutionalism, An African Debate on Democracy, Sapes books, 1991; Initiatives, Summer 1991.

18 Cf. fn. 5.

19 Mirror, October 18, 1991, and November 15, 1991.

20 I. Shivji, State and Constitutionalism, Sapem, Vol. 3, No. 5, 1990. 
on African constitutional order, hence democracy, is two-prolonged. It is characterised by the liberal and statist approach on the one hand and what he terms "a new democratic perspective" on the other. Shivji himself is the major proponent of the latter approach.

Finally, another quintessential issue of the African democracy debate relates to the contradictions between multi-partyism and democracy. In this particular regard, the Botswana political system has featured quite high.21 In an interesting book edited by Molomo and Mokopakgosi22 a strongly plausible argument is being raised regarding the hegemonic setup to which Botswana multi-partyism is anchored. The backbone of this contention is that despite the existence of a multiplicity of political parties, the ruling party enjoys institutionalised political hegemony and supremacy that tends to throttle democratic transformation. Tsie23 captures this point cogently:

"There is a general consensus among scholars of contemporary Botswana that Botswana's liberal democratic experiment cannot just be dismissed as mere neo-colonial petty-bourgeois democracy nor can it simply be eulogised as 'a shining example of democracy' in Africa. All protagonists in the debate on the nature, form and content of Botswana's liberal democracy are further agreed that there has not been a transfer of power from one political party to another since independence and that, if anything Botswana is a dominant one-party system through the ballot box. Therefore, the stability of Botswana's liberal democracy is questionable. Its durability remains to be seen." (my emphasis)

Molutsi24 also argues that Botswana's political system is to all intents and purposes, a oneparty system. We now tum to an extrapolation of the issues discussed above in order to contextualise them within Lesotho politics.

\section{Any Sign-Posts of Democracy in Lesotho?}

Lesotho presents one of the most bizzare political complexities of Southem Africa. A very small country geographically covering about $30,000 \mathrm{sqkm}$ and completely surrounded by South Africa. Its population is estimated at about 1.6 million people. The politics of Lesotho since independence have clearly been characterised by a deepseated constitutional

21 A. Molokomme, Multi-party System in Botswana, in: I. Shivji (ed.), State and Constitutionalism, An African Debate on Democracy, Sapes books, 1991.

22 ibid.

23 Tsie, 1991.

24 Molutsi, 1991. 
crisis $^{25}$; lack of a popularly elected government, hence the severe legitimacy crisis of the state up to date; rule by brute force, rather than consensus, which has tremendously undermined human rights and accountability; the heavy dependence of government on foreign support through a clear-cut collaboration of the bureaucratic bourgeoisie and international bourgesoisie of various capitalist countries (e.g. South Africa); lack of well-coordinated and synchronised popular struggles which could have long exerted pressure for democratic transformation; massive corruption and the pervasiveness of narrow lineage politics and politics of personality cult.

The above factors constitute the lynch-pin of Lesotho's political crisis. It is these very factors, among others, that acted as a political midwife during the birth of military dictatorship in 1986. Thus the enormous challenge of democracy in Lesotho ipso facto calls for meaningful solutions to the crisis outlined above. Since independence itself there have never been any political sign-posts to democratic rule in Lesotho. Even contemporary politics in Lesotho does not, by any means, indicate any such sign-posts. To illustrate this point more clearly the leader of the Basotho National Party (BNP) - the party which clung to power by force since 1970 until it was removed by more brute force in 1986 - said in December 1965:

"I know that after five years you could cast us among useless thoms ... But in order that you should re-elect us during the next election our duty is to fulfil the promises we made to you." 26

It is quite clear from the above quote that the BNP, therefore, was merely concerned with "election" and "re-election" into power rather than institutionalising democratic rule. This is the characteristic feature of all petty-bourgeois political parties whose main concern becomes self-sustenance and self-perpetuation in power as a purely class project rather than a national project. This begs an important question that needs to provoke all debate and discourse on democracy in Africa: What is the nature of the post-colonial state in Lesotho? To answer this question sufficiently would, no doubt, require a full-fledge paper which provides a detailed treatise. For our purposes here it will suffice to argue that the postcolonial state in Lesotho is fundamentally a bureaucratic bourgeois state à la Shivji which due to periodic political developments has also changed faces to bureaucratic-militarychieftainship alliance and to the present bureaucratic-military oligarchy.

The post-colonial state in Lesotho, thus, serves not only its own corporate interests, but further serves the interests of both the modern elite, and to some extent, the traditional elite

25 J. Bardill / J. Cobbe, Lesotho: Dilemmas of Dependence in Southem Africa, Westview Press, London 1985.

26 Ibid. 
as well as foreign capital. Thus, much as it may be argued that the post-colonial state enjoys some relative autonomy from various social classes, it is by no means politically aloof from the class struggle that is a feature of Lesotho's contemporary political economy. An antithesis of this viewpoint is that presented by $\mathrm{Holm}^{27}$ :

"... Holm contends that, far from being responsible to dominant intemal and extemal classes (Marxists view) or spanned by a popularity of vested interests, based on both class and non-class forces (the populist view), the state in Lesotho has in many ways become the dominant force in society, pursuing objectives that are independent of and frequently at variance with those of other groups and classes." (my emphasis)

This liberal predisposition that conceptualises the state as an independent entity above civil society and aloof from class struggles is then supported by the following argument. It is argued that corruption and embesslement of public funds by the bureaucratic bourgeoisie in Lesotho is a clear-cut indication that the principal objective of the post colonial state is selfaggrandizement of the wielders of state power. This objective may be motivated by sheer "political ambition and economic greed or by more complex desires to leave a mark on prosperity".28

Having introduced a somewhat inexhaustive debate on the post-colonial state we now turn to an historical excursion of political developments in Lesotho with the primary objective of inquiring as to whether there have been or there are any sign-posts towards democratic transformation.

\section{Political Process and Democratisation: Whither Lesotho}

For the purposes of this brief paper we will not provide a detailed historical record of Lesotho's political process nor do we proffer a profound analysis of the profile of political parties. Our perspective, though historical in both form and content, will be rather sketchy and synoptic so as to allow enough room for a detailed discussion of the contemporary military politics.

The ma jor political parties that shaped Lesotho's post-colonial political landscape were the following: Basotho National Party BNP (1958), Basotho Congress Party - BCP (1952), the Communist Party of Lesotho - CPL (1962), Marema-tlou Party - MTP (1957) and Freedom Party (1961). The last two parties merged together in 1963 to from the Marema-tlou Freedom Party (MFP). As the above dates indicate the above mentioned political parties owe

27 J. Bardill / J. Cobbe, fn. 25.

28 Ibid. 
their origins to the anti-colonial nationalist struggles which laid a foundation for national independence which was attained on the 4th October, 1966. The Basotho National Party (BNP) was thrust into state power through the 1965 general election. As a result the BNP did not only become the first political party to assume power in the post-colonial era but managed through manipulation, force and fiat to stay in power until 1986 when it was unecromoniously slided from power through a military coup.

The outcome of the 1965 general election was as indicated in Table 1 below:

Table 1: General Election for the National Assembly 1965

$\begin{array}{lrcc}\text { Party } & \text { No. of votes } & \text { \% of total votes } & \text { No. of seats } \\ \text { BNP } & 108,162 & 41.6 & 31 \\ \text { BCP } & 103,050 & 39.67 & 25 \\ \text { MFP } & 42,837 & 16.5 & 4 \\ \text { MTP } & 5,697 & 2.2 & 0 \\ \text { Independents } & 79 & 0.03 & 0 \\ \text { Total } & 259,825 & 100.00 & 60\end{array}$

Source: J. Bardill / J. Cobbe, 1985 (cf. fn. 25)

The fact that in Table 1 above there is both MFP and MTP was due to the 1964 split. 29 The table above indicates a clear-cut landslide victory of the BNP with a heavy contestation from the BCP. As such, in the post-independence period, the BCP became the major opposition party whilst the MFP and MTP were somewhat politically insignificant as an effective opposition. The CPL was banned at the age of 8 in 1970. As such its political strategy, as an opposition, has not beed widely canvassed partly as a result of the banning. The CPL was unbanned in 1991. The first post-independence election was held in January 1970, Tuesday 27 th.

\begin{abstract}
"Although early retums revealed important swings to the ruling BNP in BCP's former stronghold in the Northwest, these were soon countered by even more dramatic swings to the BCP in the previously BNP dominated mountain regions. By Thursday evening the BCP had clearly won by a confortable margin. The full results were never released officially, but reliable estimates gave the BCP 36 seats, the BNP 23 and the MFP 1."30
\end{abstract}

29 For details see: M. Khaketla, Lesotho 1970, Morija printing press.

30 J. Bardill / J. Cobbe, fn. 25. 
This election was declared null and void by the ruling BNP on the pretext of intimidation and harassment and on the 31st January 1970 the then leader of the BNP announces "I have seized power. I am not ashamed of it". The state of emergency was then declared. Since then the BNP managed to institutionalise its political monopoly not exactly in the sense that this process took place in Botswana. In Botswana it is more or less characterised by a politically subtle sophistication of the ruling BNP strategies. In Lesotho there has existed a strong element of political control and at times brute force, legalised through (a) the state of emergency which was imposed in 1970 and lifted in 1973 (b) Internal Security Act of 1974 (c) Anti-communism Act of 1970 which banned the 1962 communist party of Lesotho (d) suspension of the 1966 Constitution due to the alleged "defects of Westminster democracy", and (e) the strengthening of the security apparatus as the repressive arm of the post-colonial state and (f) the institutionalisation of political control over local government through the 1969 Local Government (Repeal) Act. 31

Due largely to the state application of brute force and manipulation in political process effective opposition almost fizzled off. Consequently, the BCP resorted to violence through the establishment of the Lesotho Liberation Army (LLA), in 1979, through which South Africa managed to fight a proxy war against Lesotho. It was partly due to this proxa war, direct South African military incursions and economic blocades that the BNP was toppled by the military in 1986 .

The second post-independence election was held in 1985 characterised by overt BNP manipulation which relegated the whole process to a political sham. The BNP manipulation included the official requirement that all political parties intending to stand for election register with M 1000 each. This was meant to exploit the scarce financial resources of the opposition parties in favour of the state-financed BNP. The second demand was that all political candidates should bring along with them about 500 voters for their nomination to the poll stations to qualify. The current draft electoral law produced my the military government proposes a registration fee of M 500 per candidate which may still prove exorbitant to the new political parties in particular.

This was a clear-cut subversion of the internationally accepted principle of the secret ballot aimed at intimidation. It was, thus, not surprising that the BNP emerges "victorious" out of this political fake. Then it was conveniently pronounced that the BNP had returned to power unopposed.

31 R. C. Leduka, Aspects of Urban Management in Lesotho: The Case of the City of Maseru, paper presented to RUPSEA Conference on Urban Management in Southem and Eastem Africa, 7 - 10 October, 1991, Malawi, Lesotho, 1979. 
Up to date many other parties have emerged in Lesotho's political scene. These include the United Democratic Party - UDP (1967), the Basotho Democratic Alliance - BDA (1984), National Independence Party - NIP (1984), the United Fatherland Front - UFF (1985), the Lesotho Labour Party - LLP (1991), the popular Front for Democracy - PFD (1991), the Kopanang Basotho Party - KBP and the Liberal Party of Lesotho - LPL (1991). All in there are presently about 12 political parties in Lesotho which are flexing their muscles in preparation for the so-called retum-to-democracy by May, 1992. This mushrooming of political parties, particularly in 1991 may be, in part, a reflection of the profound disillusionment of Basotho with the traditional political parties.

The military assumed power in 1986 through a coup d'état in Lesotho. The factors that led to and the foundations of this coup have been discussed elsewhere. 32 Our ma jor concern in this section of the paper is to interrogate the present political process which is stagemanaged by the military and ask ourselves a question whether Lesotho is heading for democracy or merely "civilianised" multi-partyism at best. The worst scenario is that Lesotho may not even experience elections in 1992. Witness for instance the change of election date by the military without providing another definite date. When the military rule established itself in 1986, it was generally argued, as is the case throughout Africa, that it was merely to fight against comuption, bring about national reconciliation and unity after which the army will then gracefully retire back to the barracks. We have now grown six years under the military yoke, with absolutely no sign-posts of retum to civilian rule let alone democratic rule. It has now come to light that the military was up to entrenching itself in power if not destroying their bridges for return to the barracks. Repression and authoritarian rule reigned since 1986.

(a) The 1986 Suspension of Political Activities Order No. 4 was ultimately abolished in 1991 while the notorious Internal Security Act of 1974 still remains in the statute books. (b) Increased violence involving atrocious murders and armed robbery with hardly any signs of bringing the culprits to book, (c) Legal institutionalisation of despotism through promulgation of such notorious laws as the National University of Lesotho (Amendment) Order No. 21, and the Teaching Service (Amendment) Order No. 12,33 (d) Rule by decree and state of emergencies, (e) Suppression of opposition and clamp-down on organised trade union strikes including the current refusal of the government to register an independent trade unions federation - the Congress of Democratic Unions (CDU), (f) the apparent reluctance on the part of the military junta to openly set the "democratisation" process in motion and finally ( $\mathrm{g}$ ) the disturbing see-saw of military coups (about three up to date, including the

32 See $K$. Matlosa, The Impact of the Military on Lesotho's Policy and Society: A preliminary overview, IFAA occasional paper (forthcoming) 1991.

33 For details see $K$. Matlosa, The State, Intelligentsia and Academic Freedom in Lesotho, Sapem, Vol. 4, No. 7, 1991. 
1985 one) involving, factional intrigues within the regime. The latest of this intrigues involves the dethronement of the King by King's order No. 14 of 1990 and his being exiled to London and the dethronement of the principal chief of Thaba-Bosiu by Notice No. 155 (chieftainship Notice) of 1991, 5th September which both sparked a political furore. Due to massive pressure mounted by the people of Thaba-Bosiu against government decision to dethrone chief Khoabane the government has rescinded its decision and reinstated Khoabane on the 18 November, 1991.34

Under the military rule it does seem that Lesotho is poised to become a "Kingdom without Kings" if the recent trends of events is anything to go by. We have thus far provided a sketchy outline of political processes in Lesotho since independence. We have established that there are no clear-cut political sign-posts to democratisation as of now. The question that still remains is whether Lesotho will enjoy the fruits of democracy by 1992. The conclusion section of this paper, therefore, attempts to address this issue, though in a rather schematic fashion.

\section{Conclusion}

There is clearly no doubt that Lesotho's road to democracy is a bumpy and thorny one. Firstly, it is yet not clear whether Lesotho is really heading for democracy. Secondly, it is yet not clear whether 1992 will witness a merely "civilianised" multi-partyism without any ingredients or flavours of democracy. Finally, it is as of yet not clear as to whether, if that democracy comes about, it would not be just a "militarised democracy". Let us provide some meat to the above bones. There is a likelihood that Lesotho is indeed not heading for democracy, at least not by 1992 . Consider the following in tandem with the above observation: (a) The government has not as yet prepared a voter's roll. (b) Though the government has just promulgated an electoral law it has not as of yet established an electoral of fice/ commission. (c) There is currently an alarmingly upward spiral of armed violence in the country which may hamper a smooth democratic transition in Lesotho and (d) developments in South Africa may also have their own imprint on Lesotho whether positively or negatively. (e) The government has just begun fund-raising for the electioneering process which is roughly estimated to cost 11.1 Million Maloti (US\$ 4 Million).

Incidentally, the current national budget does not reflect any budget earmarked for this purpose. 35 (f) The government has not as yet established the exact number of constituencies to be contested by political parties, neither has it established the office of the chief

34 Mirror, November 15, 1991.

35 See K. Klein / L. Wells, Lesotho: A Pre-Election Assessment Report, Intemational Foundation for Electoral Systems, Washington, 1991. 
electoral officer. $(\mathrm{g})$ The nature of the ballot system to be operational during the elections has not as yet been finalised and publicised.36 This task is critical of the public is to be alerted well in advance as to what procedure is to be followed during the elections. This is supposed to be part of political education of the people before elections. (h) The government has yet to establish how many voters are eligible to exercise voting in order to complete the voters' roll. This may be done either through a population census or registration of voters. The govemment has to make up its mind as to which approach to adopt in this regard. Consequently our scenarios for Lesotho's future are as followes:

(a) The 1992 election is likely to be post-poned indefinitely if not cancelled.

(b) The 1992 election is likely to take place but may be a fraudulent, and probably violent episode.

(c) Yet again another military coup may not be ruled out. Any military coup that may happen is likely to be backed by some political party aimed at being thrust into power. At the same time such a political party is likely to make certain political guarantees and concessions to the military interests.

(d) Yet another scenario is the possibility of a camouflaged democracy which may engender the entrenchment of the military in Lesotho politics behind the facade of multi-party democracy. 37 This will be nothing else but a militarised democracy for want of a better phrase.

(e) The 1992 election may be a genuine democratic exercise which may redeem the counry from the present politico-constitutional malaise.

The possibility (d) above is the most problematic scenario. Our thinking is that this may happen only if there is an effective popular struggle pursuing a mass-based democratic project. This clearly accords with Shivji's earlier definition that democracy is a struggle. Another component to this scenario is the external pressure upon the military regime, i.e. by the donor community. Thus the fusion of domestic popular pressure and external pressure may bring about a genuine democratic transformation. All that we can project is that, if scenario (d) above fails, Lesotho is likely to be thrust into an abysmal politicoconstitutional crisis which will be much more profound than what has been experienced in the past 25 years of independence. That politico-constitutional crisis will also exacerbate the economic crisis since it will, with all certainty, scare off foreign aid and investment on which Lesotho overwhelmingly depends for survival. Finally, the present political process in Lesotho, state-managed by the military, may not be worth the accolades of a democratisation process which the officialdom tends to accord to it.

36 See ibid.

37 See K.Matlosa, fn. 33. 
duties) as against direct taxation, thereby giving the entire tax system a definitely regressive slant. Income taxation being based on prohibitively high progressive rates, its administrative application became uneven and inefficient. At the same time, the country's commercial isolation virtually wiped out customs duties as the major source of revenue from indirect levies. The study emphasizes the effects which the gradual systemic distortion had upon the administrative side. Assessment and tax collection deteriorated due to staffing problems caused by below-subsistence level emoluments. The effects are still visible in the age gap and loss of experienced personnel that are a consequence of high fluctuation rates out of the public service.

The paper finally examines the possibilities and prospective consequences of the step-bystep fiscal policy revision that has been implemented since 1987, as a collateral to the two successive Economic Recovery Programmes agreed upon with the World Bank and IMF.

\section{Multi-Partyism versus Democracy in Southern Africa: "Whither Lesotho"}

\section{By Khabele Matlosa}

In many African countries, the debate on multi-partyism has become one of the most important and most ardently disputed issues in constitutional law and on the political scene. Whereas Western countries favor the concept of multy-partyism without exception, the African debate is characterized by a more diversified and a more critical view. The African dispute is taking into consideration the situation of the political systems involved and the legal structure provided within the specific countries concerned. And it does not separate politics and constitutional law artificially.

The case study on multi-partyism in Lesotho may be exemplary in this sense. It is, at the same time, uncomparable and unique, as Lesotho economic, social and political background does not compare to many other African countries.

The article begins with contrasting definitions of the concepts of multi-partyism and democracy in a Western and in an African setting. It then continues with a synopsis of the African democracy debate past and present. Finally, the author provides a detailed analysis of democracy in Lesotho itself. He concludes that the "military democracy" Lesotho is facing may not lead to true multi-partyism in the near future. Nevertheless, the options and possibilities that do exist for Lesotho are reviewed and critically discussed. 